Published in final edited form as:

Bone. 2014 July ; 64: 39-46. doi:10.1016/j.bone.2014.03.044.

\title{
Bone marrow fat accumulation accelerated by high fat diet is suppressed by exercise
}

\author{
Maya Styner ${ }^{1}$, William R. Thompson ${ }^{1}$, Kornelia Galior ${ }^{1}$, Gunes Uzer ${ }^{1}$, Xin Wu$^{1}$, Sanjay \\ Kadari $^{1}$, Natasha Case ${ }^{1}$, Zhihui Xie ${ }^{1}$, Buer Sen ${ }^{1}$, Andrew Romaine ${ }^{3}$, Gabriel M. Pagnotti ${ }^{4}$, \\ Clinton T. Rubin ${ }^{4}$, Martin A. Styner ${ }^{2,3}$, Mark C. Horowitz ${ }^{5}$, and Janet Rubin ${ }^{1}$ \\ ${ }^{1}$ Department of Medicine, University of North Carolina, Chapel Hill, NC \\ ${ }^{2}$ Department of Computer Science, University of North Carolina, Chapel Hill, NC \\ ${ }^{3}$ Department of Psychiatry and Computer Science, University of North Carolina, Chapel Hill, NC \\ ${ }^{4}$ Department of Biomedical Engineering, State University of New York, Stony Brook, NY \\ ${ }^{5}$ Department of Orthopedics and Rehabilitation, Yale University, New Haven, CT
}

\begin{abstract}
Marrow adipose tissue (MAT), associated with skeletal fragility and hematologic insufficiency, remains poorly understood and difficult to quantify. We tested the response of MAT to high fat diet (HFD) and exercise using a novel volumetric analysis, and compared it to measures of bone quantity. We hypothesized that HFD would increase MAT and diminish bone quantity, while exercise would slow MAT acquisition and promote bone formation. Eight week-old female C57BL/6 mice were fed a regular (RD) or HFD, and exercise groups were provided voluntary access to running wheels (RD-E, HFD-E). Femoral MAT was assessed by $\mu \mathrm{CT}$ (lipid binder osmium) using a semi-automated approach employing rigid co-alignment, regional bone masks and was normalized for total femoral volume (TV) of the bone compartment. MAT was 2.6-fold higher in HFD relative to RD mice. Exercise suppressed MAT in RD-E mice by more than half compared with RD. Running similarly inhibited MAT acquisition in HFD mice. Exercise significantly increased bone quantity in both diet groups. Thus, HFD caused significant accumulation of MAT; importantly running exercise limited MAT acquisition while promoting bone formation during both diets. That MAT is exquisitely responsive to diet and exercise, and its regulation by exercise appears to be inversely proportional to effects on exercise induced bone formation, is relevant for an aging and sedentary population.
\end{abstract}

\footnotetext{
(c) 2014 Elsevier Inc. All rights reserved.

Corresponding author: Maya Styner, University of North Carolina department of medicine, division of Endocrinology, CB 7170, 5002 Burnett Womack, 160 Dental Circle, Chapel Hill, NC 27599-7170, +1-919-843-0711, mstyner@med.unc.edu.

Publisher's Disclaimer: This is a PDF file of an unedited manuscript that has been accepted for publication. As a service to our customers we are providing this early version of the manuscript. The manuscript will undergo copyediting, typesetting, and review of the resulting proof before it is published in its final citable form. Please note that during the production process errors may be discovered which could affect the content, and all legal disclaimers that apply to the journal pertain.
} 


\section{Keywords}

Exercise; Marrow Adipose Tissue; Micro-CT; Quantitative Image Analysis; Bone Micro Architecture; Lipid

\subsection{Introduction}

As obesity and its associated metabolic sequelae reach epidemic proportions globally, considerable effort has been invested in understanding the distinct roles of specific adipose depots in contributing to disease states. Besides the fat accumulating in visceral and subcutaneous depots, adipose tissue found in the bone marrow space (marrow adipose tissue; MAT) is of clinical interest. The adipocytes that form MAT are generated in the bone marrow from mesenchymal stem cells (MSC), and are more closely related to osteoblasts than other cells of mesenchymal origin [1]. Both mouse and human studies indicate that conditions of increased bone formation are associated with decreased marrow fat [2,3], an inverse relationship thought to be due to the preferential allocation of MSC into bone forming osteoblasts rather than adipocytes [4].

Human data supports a clinical relationship between increased MAT and low bone mass; this has been demonstrated in anorexia nervosa [5], paraplegia [6] and post-menopausal osteoporosis [7]. In a study of young adults, marrow fat was inversely correlated with measures of vertebral bone density and femoral cortical bone area [8]. Further, as precursors for MAT are critical components of the hematopoietic-MSC niche, an alteration in MAT is likely to influence MSC function, either through local autocrine effects, or through physical encroachment [9], which could compromise the ability to regenerate damaged connective tissues.

The physiology of MAT is poorly understood, both in terms of its dependence and effect on MSC lineage allocation and as a potential storage depot for excess calories [10].

Importantly, whether excess calories or calorie expenditure during exercise can regulate the quantity of MAT, as it does in non-marrow adipose depots, is unknown. A recent positive correlation between bone marrow fat and intrahepatic lipid, intramyocellular lipid, and serum triglyceride level suggests that MAT might serve as a storage depot for excess calories [11]. MAT has a unique composition of lipid species [1] and recently has been shown to have a gene expression profile that overlaps with brown as well as white adipose tissue [12]. Interestingly, starvation diets appear to increase MAT depots [13, 14] but how high fat diet affects this lipid compartment is unclear.

Exercise is universally recognized as a means of suppressing obesity-associated white adipose tissue depots as well as enhancing bone density and muscle mass [15-18]. Skeletal loading stimulates bone formation as has been widely shown in humans [19] and animals [20-22]. Our laboratory has demonstrated that mechanical input, analogous to exercise, promotes cytoskeletal complexity and activation of $\beta$ catenin invitro, signals associated with osteoblastogenesis [23-31]. These effects translate to the in-vivo physiology as well, as MSC extracted from exercising mice have increased $\beta$ catenin and a reduced capacity for adipogenesis [20]. 
The present study was designed to test the effects of diet and exercise on MAT and bone. We hypothesized that a high fat diet would increase MAT analogous to increases expected in white adipose tissue, and thus MAT might, besides representing a pathologic diversion of MSC into adipocytes, function as an energy storage depot. Further, we asked if changes in MAT would correlate with measures of bone quantity. To answer whether diet and exercise affect MAT, we applied a quantitative, volumetric method for measuring and localizing marrow adiposity [32]. This method identified the presence of lipid by its ability to bind osmium, a method widely used to identify adipose tissue [33,34]. As osmium signal can be separated from both marrow and bone by a high CT density [35], we were able to analyze $\mu \mathrm{CT}$ images to obtain volumetric assessment of marrow fat.

Here we quantified MAT in mice fed regular or high-fat diets and provided access to voluntary wheel running in exercise groups. We show that diet and exercise strongly influence MAT quantity in opposite directions. While the exercise reduction in MAT was associated with increased bone quality, the increased MAT due to six weeks of high fat diet did not adversely affect bone. Our results are the first to quantify an increase in MAT in response to diet, and a reduced accumulation of MAT in response to running exercise, changes that were inversely correlated to bone quantity.

\subsection{Materials and Methods}

\section{Animals and Diet}

The UNC IACUC approved the use and care of animals in the study. Eight-week old female C57BL/6 mice $(n=20)$ were randomly assigned to one of two diets for a period of 6 weeks: 1) regular diet, RD, low in fat (PicoLab Mouse Diet 20, Item \#: 5058) or 2) a high-fat diet, HFD diet comprised of $45 \%$ fat, $35 \%$ carbohydrate and $20 \%$ protein, with the majority of fat calories derived from lard (Research diets, DIO Series Diets Item \#12541). Mice were fed ad libitum; the grams of food consumed were weighed and calories per gram calculated. In a second study, 10-week old, skeletally mature, C57BL/6 mice were studied to assess effects of exercise on marrow adiposity. Female C57BL/6 mice were used because this gender and strain has been shown to be highly motivated to run within the voluntary wheel running protocols [36].

\section{Exercise Intervention}

Mice in either diet group were allocated to an exercise intervention for 6 weeks. The groups were as follows: 1) Regular Diet, RD ( $n=5), 2)$ Regular Diet Exercise, RD-E ( $n=5), 3)$ High fat, HFD $(n=5), 4)$ High Fat Exercise, HFD-E $(n=5)$. Change to HFD and/or access to the exercise wheel were commenced simultaneously. Both control and running mice were individually housed for the duration of the running experiments so that running could be tracked for each mouse. Food consumption and exercise was voluntary, mice were weighed weekly. A voluntary, running wheel exercise intervention was used as previously described [36]. The wheels were suspended above the cage floor by metal brackets. Exercise wheel use was monitored using a Mity 8 Cyclocomputer (model CC-MT400), recording distance, average speed, and daily running time. Control mice were housed similarly (one mouse/ cage) but did not have wheel access. 


\section{Specimen harvest and preparation}

Running wheels were removed 24 hours prior to harvest. Animals were weighed and euthanized by $\mathrm{CO}_{2}$ inhalation followed by decapitation. Perigonadal fat pads were collected and weight normalized to body weight. The visceral fat pad that is the female-equivalent for the epididymal fat pad is the perigonadal fat pad (also known as the parametrial fat pad[37]). Right and left femur and tibia were harvested and soft tissue dissected away, tibiae were prepared for $\mu \mathrm{CT}$ imaging by fixation with $10 \%$ neutral buffered formalin at $4{ }^{\circ} \mathrm{C}$ overnight as previously described [38]. Femur specimens were prepared for MAT osmium stain by fixation with $10 \%$ neutral buffered formalin at $4{ }^{\circ} \mathrm{C}$ overnight, followed by decalcification with $14 \%$ EDTA for 14 days as previously described [35]. The contralateral femur was snap frozen for triglyceride assay.

\section{Triglyceride Assay}

Each mouse femur was crushed using mortar and pestle into the Cayman TG assay lysis buffer along with the addition of the protease/phosphatase inhibitors (Halt Protease Inhibitor Cocktail from Thermo scientific). After homogenization and centrifugation per the manufacturer instructions, the supernatant was analyzed for triglyceride content using Cayman's TG Assay Kit (Cayman Item Number 10010303). The triglyceride content was determined for each mouse femur and normalized to total protein content.

\section{Quantification/imaging of MAT}

Osmium staining of lipid in mouse bones has been previously described[32, 35]. Briefly, femurs were fixed with 10\% neutral buffered formalin (Fisher \#SF100-4) for 24 hours at 4 ${ }^{\circ} \mathrm{C}$. The next day, specimens were rinsed with water for $1 \mathrm{hr}$. Specimens were then decalcified in $14 \%$ EDTA at $4{ }^{\circ} \mathrm{C}$ for 14 days. Femurs were rinsed in water and cut just below the femoral head. The bones were incubated with $1 \%$ osmium tetroxide $/ 2.5 \%$ potassium dichromate for 48 hours at room temperature. Specimens were placed in cassettes and washed in water for $2 \mathrm{hrs}$.

Imaging was performed via $\mu \mathrm{CT}$ with energy of $55 \mathrm{kVp}$, integration time of 500 milliseconds, and resolution of $0.01 \times 0.01 \times 0.01 \mathrm{~mm}$ (Scanco $\mu \mathrm{CT}-35$, Scanco Medical, Bruttisellen, Switzerland). Raw, unaligned femur images were first rigidly aligned (figure 1A and 1B, 3D Slicer, www.slicer.org) [39] to present all images in a consistent fashion and to allow for superimposition of images. Bone masks were created next, starting from segmentation via standardized bone thresholds, manual contouring was performed to outline the femur in all images to designate a total femoral volume (Insight-SNAP, www.itksnap.org) [40] (figure 1C). As osmium is significantly more dense than bone, Hounsfield Unit (HU) thresholds were set for visualization of osmium as follows: low osmium from 2000-3000 HU (figure 1E/F red), mid osmium from 3000-4000 HU (figure 1E/F green) and high osmium from 4000-5000 HU (figure 1E/F blue). The lower threshold for osmium was chosen to be considerably above the $\mathrm{HU}$ for dense cortical bone [41, 42]. The contribution of potentially mislabeled cortical bone to the osmium volume is expected to be negligible [35]. The maximal threshold of $5000 \mathrm{HU}$ was chosen by inspecting the $99^{\text {th }}$ percentile over all image intensities. In between the lower and upper threshold, we divided the osmium attenuation range into three uniformly separated categories. 
Osmium within the bone mask was then quantified as volumetric $\left(\mathrm{mm}^{3}\right)$ measurements of low, mid and high osmium stain regions in the femur. Finally, the femur was subdivided into anatomical regions of interest: a) epiphysis: distal femur from knee joint to growth plate primary center of ossification (figure 1G green), b) metaphysis: distal shaft from growth plate to the distal third of the shaft as measured by the shaft length in the average image (figure $1 \mathrm{G}$ red) and c) diaphysis: proximal remainder of the shaft (figure $1 \mathrm{G}$ blue). Regional osmium volume normalized to total femoral volume TV (as \% of TV) was assessed. We reported and analyzed the $\%$ osmium (osmium in $\mathrm{mm}^{3} /$ total volume) above the mid osmium threshold of $3000 \mathrm{HU}$ (figure 1H). Of note, if the higher threshold of $4000 \mathrm{HU}$ was applied, the effects of diet and exercise were similar to those reported at $3000 \mathrm{HU}$. Aligned femoral images were averaged across all images to form an average femur image as a reference for bone visualization (figure 1D). Images were also averaged within each group separately for color-coded visualizations of the osmium densities in order to allow for visual comparisons of MAT between groups (figure 1E). The distribution and location of MAT has been previously described in [9] and was validated in RD and HFD animals using histology (supplemental figure 1).

\section{Bone microarchitecture}

Bone morphology parameters of the proximal tibial metaphysis and mid diaphysis were quantified ex vivo using high-resolution X-ray micro-computed tomography ( $\mu \mathrm{CT}$, Scanco Medical; Wayne, PA). These included bone volume (BV), bone volume fraction (BV/TV), trabecular number, thickness and spacing, and measures of cortical area and thickness. Beginning $300 \mu \mathrm{m}$ distal to the growth plate, $1200 \mu \mathrm{m}$ of the metaphysis was evaluated at $12 \mu \mathrm{m}$ resolution and $55 \mathrm{keV}$ intensity settings. A threshold for each slice was set exclusively for cortical and trabecular bone using an automated script [43]. The reconstructed solid 3D images were then used to quantify bone microarchitecture.

\section{Statistics}

Results are expressed as mean \pm SD unless otherwise specified. Statistical significance was evaluated by 2-tailed unpaired t-test or ANOVA with post hoc test (GraphPad Prism 5.04). Statistical significance is indicated on graphs and figure legends as $* \mathrm{P}<0.05, * * \mathrm{P}<0.01$, and $* * * \mathrm{P}<0.001$

\subsection{Results}

\section{Running distance, time and speed was similar in mice on HFD and regular chow diet}

Mice began running within 48 hours of exposure to running wheels, with the majority of running hours during the night cycle. Daily running times and distances were consistent with previously published studies on voluntary wheel based running [36]. There was little variability between individual mice in use of the running wheel; mice ran at least 5 hours each 24-hour period, and every single day (Table 1). Mice eating the regular diet (RD) ran a daily average of $358 \pm 65$ minutes, a time that was not significantly affected by feeding of the HFD diet, at $367 \pm 54$ minutes daily. This was an average of $10.9 \pm 3.2$ kilometers and $11.0 \pm 1.6$ respectively for RD-E and HFD-E mice. The average speed was $2.02 \pm 0.38$ (RD- 
E) and $2.14 \pm .09$ (HFD-E) km/hr. There was no significant difference between RD-E and HFD-E mice with regards to running time, distance or average speed.

\section{Six weeks of running did not significantly alter white adipose tissue}

We examined the effect of 6 weeks of ad libitum high fat feeding on young female mice (HFD diet starting at 8 weeks). In our facility, RD and HFD fed mice consumed similar daily calories, as measured by daily weight of food consumed (figure $\mathbf{2 B}$ ), as the animals limited grams consumed of the calorie-dense high fat chow (figure 2A). Six weeks after the diet change, (figure 2C), HFD-fed mice weighed $20.5 \pm 2.4$ grams, a 9\% increase over control mice $(18.8 \pm 1.2$ grams, reported as mean $\pm \mathrm{SD})$; however this was not a significant difference. Weights of HFD-fed and chow-fed mice begin to diverge after 6-8 weeks of high fat feeding, and can diverge earlier if HFD diet is initiated upon weaning [44, 45]. The fact that weights of the HFD group in our study were not statistically significant after 6 weeks might be due to gender (we used female C57BL/6 as opposed to males used in [44, 45]) or the specific formulation of the control diet (our study used PicoLab Mouse Diet 20. The Pico-lab control diet contained $21 \%$ fat-calories in contrast to the low-fat diet which contained $10 \%$ fat-calories used in [44], the 7\% fat-calorie diet used in [45]. As such, our control animals may have been heavier due to fat calories, preventing early assessment of increased total body weight.

HFD-E mice ate similar grams of chow as the non-runners (130.0 $\mathrm{g} \pm 6.4$ vs. $113 \mathrm{~g} \pm 14.6$ reported as mean $\pm \mathrm{SD}$ ) with a trend for increased calories in exercisers (figure $\mathbf{2 B}, \mathrm{p}=\mathrm{ns}$ ). At the end of the experiment the weights of HFD non-runners and HFD-E were not statistically different (HFD $20.5 \pm 1.1 \mathrm{~g}$ v. HFD-E $21.4 \pm 0.9 \mathrm{~g}, \mathrm{p}=\mathrm{ns}$ ). The only statistically significant divergence in weight was between the RD runners and non-runners, with runners weighing nearly 4 grams more ( $R D 18.8 \pm 1.2 \mathrm{~g} \mathrm{v}$. RDE $22.3 \pm 2.6$, figure $2 \mathrm{C}$ ).

Excised perigonadal fat pads were normalized to total body weight to control for variations in individual mouse size. Both groups of HFD fed mice showed significant increases in the perigonadal fat weight normalized to body weight (figure 2D, $\mathrm{p}<0.05$ ). Perigonadal fat percentage increased by $46 \%$ in the setting of HFD diet (figure 2D, $\mathrm{p}<0.05$ ). Running did not attenuate perigonadal fat percent in either RD-E or HFD-E at the 6-week time period of the experiment (percent change of $-0.4 \%$ for RDE vs RD and $+6.0 \%$ for HFD-E vs HFD, $\mathrm{p}=\mathrm{ns}$ for both, figure 2D).

\section{Exercise suppressed marrow adipose tissue (MAT) despite high fat diet}

MAT was analyzed using volumetric $\mu \mathrm{CT}$ assessment of the osmium stain from the proximal diaphysis to the distal epiphysis (figure 1). Qualitative assessment was achieved by viewing average images of the femur ( $\mathrm{n}=5$ per group) superimposed with color-coded osmium density maps, presented in the sagittal, coronal and axial plane. The sagittal and coronal plane images demonstrated MAT at the level of the growth plate and into the shaft of the diaphysis (figures 3A,B). Distal to the growth plate, a reduced amount of osmium was detected. However, relative to the distal epiphysis, increased osmium staining was noted in the metaphysis. The osmium density images allow localization of fat throughout the full bone suggesting significant spatial variation when viewed across axial slices (figure 3C). To 
be clear, this is not a representative image: each image in figure 3 is an averaged image of $\mathrm{n}=5$ bones per group obtained by overlaying images. As noted in methods, the data shown is osmium percent of total femoral volume (TV) above a threshold of $3000 \mathrm{HU}$. In order to visualize the distribution of MAT, we present the images in the sagittal (figure 3A), coronal (figure 3B) and axial (figure 3D) planes. This data, analyzed by region, is shown in detail in Table 2.

At all sites imaged, HFD stimulated a significant increase in MAT compared to that in mice fed a control diet. Selecting the metaphysis, volumetric MAT increased from $8.5 \pm 3.4 \%$ osmium volume/total volume to $22 \pm 8.2$ (Table 2 and figure 3E, $\mathbf{p}<\mathbf{0 . 0 5}$ ). Figure $3 \mathbf{E}$ shows that HFD caused and increase in MAT to 2.6-fold relative to RD. The increase in the marrow compartment was similar to diet-induced increases in perigonadal fat (figure 2D). As such, MAT was found to be highly responsive to dietary fat feeding.

In animals fed RD, exercise significantly reduced accumulation of MAT. The MAT in the imaged femur (epiphysis + metaphysis + diaphysis) in runners was half that measured in non-runners (Table 2, $\mathrm{p}<0.05$ ). Running prevented MAT accumulation at all sites except the diaphysis in RD-E. The change at the metaphysis is shown in figure $\mathbf{3 E}$ with mean $\pm \mathrm{SD}$ as in Table $2(\mathrm{p}<0.05)$.

Exercise reduction in MAT was even more robust when MAT acquisition was stimulated by HFD. High fat diet increased MAT by 2.6-fold in sedentary animals (compare HFD to RD); exercise almost entirely prevented this dietary increase. Comparing HFD-E to HFD sedentary, exercise reduced MAT in the metaphysis by 2.3 -fold (figure $3 \mathrm{E}, \mathrm{p}<0.05$ ).

MAT quantity in non-metaphyseal sites also responded to both diet and exercise. The increase in MAT due to dietary fat was visualized in all regions of the distal femur proximal to the growth plate with the exception of the diaphysis, which appeared to be spared from increases in MAT due to diet, and unaffected by exercise (Table 2). The diaphyseal region had very little MAT as measured by osmium in either diet group, which may limit any valuation of change. Epiphyseal MAT also increased with HFD feeding, but the running effect on MAT in the epiphysis did not reach statistical significance (1.5-fold less in RDE vs. RD, 1.4-fold less in HFD-E vs. HFD, table 2), again perhaps limited by the small amounts of volumetric fat found in this compartment.

Biochemical assessment of triglyceride/protein in the distal femur was increased in HFD-fed mice, correlating with MAT/osmium data, but did not reach statistical significance (figure 3F, triglyceride level was $274 \pm 72$ in RD vs $226.4 \pm 67$ in RDE and $314 \pm 68$ in HFD vs $276 \pm 52$ in HFD-E). Exercise, in agreement with the volumetric MAT measure, resulted in a trend toward reduced triglyceride/femur protein

\section{MAT response to exercise in skeletally mature mice}

We next wished to ascertain if mice that had reached adulthood would use the running wheel as much as when allowed access earlier, and to respond to exercise in terms of limitation of MAT. We introduced 10-week old C54BL/6 females fed a regular RD diet to voluntary running wheels. Adult females began running within $48 \mathrm{~h}$, running similar times and 
distances to their younger counterparts (Table 1, $349 \pm 64 \mathrm{~min}, 12.0 \pm 2.3 \mathrm{~km}$ ). There was little variability between the times individual animals spent on the exercise wheel, stressing that mice will run if given the opportunity.

In this experiment MAT was again significantly affected by exercise. Exercising mice had MAT volume/metaphyseal volume that was 2.1-fold less than that in non-exercising animals (Table 2 and figure 5A, p<0.05). Shown in figure 5B, the MAT response to exercise was as robust as that in younger animals.

\section{Running in regular and high fat fed mice increases bone quantity}

Bone quantity was measured in the proximal tibial metaphysis and diaphysis to assess effects of 6 weeks of HFD and exercise. HFD-fed mice had similar trabecular bone volume/ total volume (BV/TV), trabecular number (Tb.N), trabecular thickness (Tb.Th) and trabecular separation (Tb.Sp) compared to mice fed $\mathrm{RD}$, and equivalent cortical measures (Figure 4, Table 3). Six weeks of daily running induced increases in trabecular bone volume of RD mice (RD $10 \pm 0.97 \%$ vs. RD-E $14 \pm 1.9 \%$, p $<0.05$, table 3). Moreover, running increased trabecular bone volume in HFD mice (HFD $9.2 \pm 1.5$ vs. HFD-E $13 \pm$ $0.74, \mathrm{p}<0.05$, table 3). Trabecular thickness was $12 \%$ higher ( $<<0.01$ ) in RD-E compared with RD controls. In this time frame there were no significant differences in Tb.Sp or Tb.N due to exercise; however a trend upward correlates with the changes noted in trabecular $\mathrm{BV} / \mathrm{TV}$ and trabecular thickness. Cortical bone area was $0.97 \pm 0.066$ in RD and $1.1 \pm 0.080$ in RD-E ( $p<0.05$, table 3). In the HFD mice, there was a trend for increased cortical bone area with running but this was not significant. The cortical area fraction was similar between groups. Both the periosteal perimeter and the endocortical perimeter were increased in the runners (table 3). These data showed that 6 weeks of running had significant effects on bone quantity irrespective of the type of diet.

\subsection{Discussion}

Growing consensus links bone marrow adiposity with bone fragility [1] as exemplified in clinical settings including skeletal unloading [46, 47], aging [48], postmenopausal osteoporosis [49], and anorexia nervosa [13]. Imprecise quantification has previously limited assessment of changes in MAT in response to potential regulators. Here we have used a sensitive volumetric measure of marrow adiposity to demonstrate that MAT quantity is sensitive to regulation by both diet and exercise. MAT rises rapidly in response to high fat feeding without short-term effects on bone quality, and exercise induction of bone formation prevents formation of MAT. This suggests that MAT might represent an energy storage depot that can be limited by vigorous exercise.

Mice fed a high fat diet showed significant increases in marrow adiposity compared to regular diet controls that were at least as great as diet induced increases in perigonadal white adipose tissue. Surprisingly the significant increase in MAT preceded that of generalized obesity; after 6 weeks there was only a trend toward obesity in high-fat fed animals. Speculating on the rapid rise in MAT as compared to that of generalized obesity, it is possible that the increase in MAT might represent high fat calorie stimulation of marrow MSC to become adipocytes. Alternatively, it could be that lipid accumulates in pre-existing 
marrow fat cells. With the ability to carefully quantify adipose in the bone marrow, these questions can start to be addressed.

Until recently, qualitative measurements of MAT have relied on bone histology [50, 51], which cannot adequately measure the volume of fat in the marrow and is subject to site selection bias. Proton magnetic resonance spectroscopy (1H-MRS) has shown that vertebral bone marrow fat parallels visceral fat in obesity in humans [52] and has associated marrow adiposity with decreased bone mass [14]. Although 1H-MRS has been used with some success to quantify vertebral MAT in humans [52], it is more difficult in laboratory animals [53]. Furthermore, our $\mu \mathrm{CT}$-based method demonstrates superior resolution and specificity of distinguishing lipid from non-lipid tissue with osmium binding, and producing an enhanced localization effect. Assessment of marrow density by CT can also be used to estimate marrow fat, and has been used to support an effect of impact loading to improve bone quality while decreasing marrow adiposity [54]. However, local marrow density is not associated with cortical bone size, underscoring the problems with estimating MAT from localized cross-sections. The osmium-based technique used in our study further allows a focus on continuous, whole regions of bone quantified using a volumetric approach. Osmium binds avidly to lipid [55], allowing lipid to be demarcated from other components of the bone marrow space. This is advantageous when compared to other imaging modalities, which do not adequately distinguish between fat and hematopoietic compartments [56]. Additionally because the density of osmium is significantly greater than that of demineralized bone tissue stained with potassium dichromate, a clear separation between fat and bone compartments permits specific and accurate quantification of adipose volume. An additional advantage of the $\mu \mathrm{CT}$ imaging is the high resolution (commonly $\sim 10 \mu \mathrm{m}$ isotropic resolution) as compared with MR based imaging (commonly $\sim 75-100 \mu \mathrm{m}$ isotropic resolution) [57, 58]. In our study we were able to visualize increases in MAT in the metaphysis extending into the diaphysis during high fat feeding, correlating with histology and other data in the literature, indicating that marrow adipose normally shares space within the trabecular bone $[9,59]$. Further, in contrast to MR spectroscopy, $\mu \mathrm{CT}$ imaging is precalibrated [60] and does not necessitate sophisticated calibration [61]. As such, the osmium$\mu \mathrm{CT}$-volumetric analysis of MAT should prove to be an invaluable tool in understanding MAT in rodent models.

Bone quantity, in terms of trabecular and cortical volume, was not impaired by 6 weeks of high fat diet in growing animals that had not yet achieved obesity in terms of weight, despite the large increase in MAT. As the increase in trabecular bone due to exercise was equivalent between groups, the high fat diet did not appear to interfere with bone formation. These short-term experiments do not rule out that MAT could have chronic effects on bone quality. In comparison, while MAT accumulation was limited by exercise, perigonadal white adipose tissue, which also increases with HFD, was less affected, if at all, by running exercise. This suggests that these two fat depots may be differentially regulated by both diet and exercise.

When marrow-derived mesenchymal cells are exposed to adipogenic stimuli in vitro, they rapidly move toward adipocyte lineage [24, 28]. Mechanical signals restrict adipogenesis through Wnt-independent [24] and cytoskeleton dependent [27, 29, 30] generation of 
$\beta c a t e n i n$. As mouse experiments have shown that $\beta$ catenin is activated during loading [20, 62], it is possible that the effect of exercise on MAT is due to marrow MSC lineage differentiation towards osteoblasts rather than adipocytes. Alternatively, the decreased MAT accumulation during exercise might be due to energy expenditure. Our volumetric technique cannot differentiate between these possibilities.

Reduced bone quality has been noted in obese individuals despite preserved bone density measurements [63, 64]. This has significant clinical implications for exercise-based therapies and our aging population, where being sedentary is the new normal. That daily exercise suppressed the accumulation of MAT in mice could be interpreted to mean that not having access to a running wheel may itself be enough to increase MAT. Importantly, allowing mice to exercise at will, perhaps their true normal state, all but prevented increases in MAT due to high fat feeding. This suggests that exercise can "protect" against a marrow adiposity brought on by either HFD diet, aging or forced sedentary behavior. Changes in MAT resulting from diet or exercise in humans have not been measured due to technical limitations, but it is likely that our evidence showing that these measures modify murine MAT would prove to be true in humans as well.

Our study has several limitations. Our experiments have not determined if MAT can continue to increase within the marrow compartment, paralleling the almost unlimited increase in extra-marrow white adipose tissue. Further, our finding that concurrent exercise limits the MAT accumulation due to high fat feeding does not answer whether chronic increases in MAT can be minimized by exercise treatment.

In conclusion, MAT is a unique fat depot that responds rapidly to diet with increases in quantity, as do other fat depots. MAT is, further, exquisitely sensitive to exercise in growing and adult mice, changing more in short periods than do measures of bone. As such, exercise prescriptions in populations susceptible to fracture may best be quantified by alterations in marrow fat in the future. The mechanism by which diet or exercise alter MAT is not known, but the ability to reliably quantitate this compartment should allow future studies of its role in metabolism and its affect on bone formation.

\section{Supplementary Material}

Refer to Web version on PubMed Central for supplementary material.

\section{Acknowledgments}

Funding: MS: AR062097, JR: AR042360, AR056655, CR: AR 43598, EB 14351, MH: DK092759

\section{Abbreviations}

$\begin{array}{ll}\text { MAT } & \text { marrow adipose tissue } \\ \text { RD } & \text { regular diet } \\ \text { HFD } & \text { high fat diet }\end{array}$




$\begin{array}{ll}\text { RDE } & \text { regular diet exercise } \\ \text { HFD-E } & \text { high fat diet exercise } \\ \text { trabecular BV/TV } & \text { trabecular bone volume/total volume } \\ \text { Tb.N } & \text { trabecular number } \\ \text { Tb.Th } & \text { trabecular thickness } \\ \text { Tb.Sp } & \text { trabecular separation } \\ \text { Tt.Ar } & \text { total cross sectional area in the periosteal envelope } \\ \text { Ct.Ar } & \text { cortical bone area } \\ \text { Ct.Ar/Tt.Ar } & \text { cortical area fraction } \\ \text { Ct.Th } & \text { average cortical thickness }\end{array}$

\section{References}

1. Fazeli PK, Horowitz MC, MacDougald OA, Scheller EL, Rodeheffer MS, Rosen CJ, Klibanski A. Marrow fat and bone-new perspectives. Journal of Clinical Endocrinology and Metabolism. 2013; 98:935-45. [PubMed: 23393168]

2. Qiu W, Andersen TE, Bollerslev J, Mandrup S, Abdallah BM, Kassem M. Patients with high bone mass phenotype exhibit enhanced osteoblast differentiation and inhibition of adipogenesis of human mesenchymal stem cells. Journal of Bone and Mineral Research. 2007; 22:1720-31. [PubMed: 17680723]

3. Song L, Liu M, Ono N, Bringhurst FR, Kronenberg HM, Guo J. Loss of wnt/beta-catenin signaling causes cell fate shift of preosteoblasts from osteoblasts to adipocytes. J Bone Miner Res. 2012; 27:2344-58. [PubMed: 22729939]

4. Kawai M, Devlin MJ, Rosen CJ. Fat targets for skeletal health. Nat Rev Rheumatol. 2009; 5:36572. [PubMed: 19468288]

5. Bredella MA, Fazeli PK, Miller KK, Misra M, Torriani M, Thomas BJ, Ghomi RH, Rosen CJ, Klibanski A. Increased bone marrow fat in anorexia nervosa. Journal of Clinical Endocrinology and Metabolism. 2009; 94:2129-36. [PubMed: 19318450]

6. Qin W, Bauman WA, Cardozo C. Bone and muscle loss after spinal cord injury: organ interactions. Annals of the New York Academy of Sciences. 2010; 1211:66-84. [PubMed: 21062296]

7. Li X, Kuo D, Schafer AL, Porzig A, Link TM, Black D, Schwartz AV. Quantification of vertebral bone marrow fat content using 3 Tesla MR spectroscopy: reproducibility, vertebral variation, and applications in osteoporosis. Journal of Magnetic Resonance Imaging. 2011; 33:974-9. [PubMed: 21448966]

8. Di lorgi N, Rosol M, Mittelman SD, Gilsanz V. Reciprocal relation between marrow adiposity and the amount of bone in the axial and appendicular skeleton of young adults. Journal of Clinical Endocrinology and Metabolism. 2008; 93:2281-6. [PubMed: 18381577]

9. Naveiras O, Nardi V, Wenzel PL, Hauschka PV, Fahey F, Daley GQ. Bone-marrow adipocytes as negative regulators of the haematopoietic microenvironment. Nature. 2009; 460:259-63. [PubMed: 19516257]

10. Baglioni S, Cantini G, Poli G, Francalanci M, Squecco R, Di Franco A, Borgogni E, Frontera S, Nesi G, Liotta F, Lucchese M, Perigli G, Francini F, Forti G, Serio M, Luconi M. Functional differences in visceral and subcutaneous fat pads originate from differences in the adipose stem cell. PLoS One. 2012; 7:e36569. [PubMed: 22574183]

11. Bredella MA, Gill CM, Gerweck AV, Landa MG, Kumar V, Daley SM, Torriani M, Miller KK. Ectopic and Serum Lipid Levels Are Positively Associated with Bone Marrow Fat in Obesity. Radiology. 2013 
12. Krings A, Rahman S, Huang S, Lu Y, Czernik PJ, Lecka-Czernik B. Bone marrow fat has brown adipose tissue characteristics, which are attenuated with aging and diabetes. Bone. 2012; 50:54652. [PubMed: 21723971]

13. Fazeli PK, Bredella MA, Freedman L, Thomas BJ, Breggia A, Meenaghan E, Rosen CJ, Klibanski A. Marrow fat and preadipocyte factor-1 levels decrease with recovery in women with anorexia nervosa. Journal of Bone and Mineral Research. 2012; 27:1864-71. [PubMed: 22508185]

14. Devlin MJ, Cloutier AM, Thomas NA, Panus DA, Lotinun S, Pinz I, Baron R, Rosen CJ, Bouxsein ML. Caloric restriction leads to high marrow adiposity and low bone mass in growing mice. Journal of Bone and Mineral Research. 2010; 25:2078-88. [PubMed: 20229598]

15. Ozcivici E, Luu YK, Adler B, Qin YX, Rubin J, Judex S, Rubin CT. Mechanical signals as anabolic agents in bone. Nat Rev Rheumatol. 2010; 6:50-9. [PubMed: 20046206]

16. Walhin JP, Richardson JD, Betts JA, Thompson D. Exercise counteracts the effects of short-term overfeeding and reduced physical activity independent of energy imbalance in healthy young men. J Physiol. 2013

17. Thompson D, Karpe F, Lafontan M, Frayn K. Physical activity and exercise in the regulation of human adipose tissue physiology. Physiol Rev. 2012; 92:157-91. [PubMed: 22298655]

18. Warden SJ, Fuchs RK, Castillo AB, Nelson IR, Turner CH. Exercise when young provides lifelong benefits to bone structure and strength. J Bone Miner Res. 2007; 22:251-9. [PubMed: 17129172]

19. Trudel G, Coletta E, Cameron I, Belavy DL, Lecompte M, Armbrecht G, Felsenberg D, Uhthoff HK. Resistive exercises, with or without whole body vibration, prevent vertebral marrow fat accumulation during 60 days of head-down tilt bed rest in men. Journal of Applied Physiology. 2012; 112:1824-31. [PubMed: 22442031]

20. Menuki K, Mori T, Sakai A, Sakuma M, Okimoto N, Shimizu Y, Kunugita N, Nakamura T. Climbing exercise enhances osteoblast differentiation and inhibits adipogenic differentiation with high expression of PTH/PTHrP receptor in bone marrow cells. Bone. 2008; 43:613-20. [PubMed: 18567552]

21. David V, Martin A, Lafage-Proust MH, Malaval L, Peyroche S, Jones DB, Vico L, Guignandon A. Mechanical loading down-regulates peroxisome proliferator-activated receptor gamma in bone marrow stromal cells and favors osteoblastogenesis at the expense of adipogenesis. Endocrinology. 2007; 148:2553-62. [PubMed: 17317771]

22. Rubin CT, Lanyon LE. Regulation of bone formation by applied dynamic loads. The Journal of bone and joint surgery. American volume. 1984; 66:397-402.

23. Case N, Thomas J, Xie Z, Sen B, Styner M, Rowe D, Rubin J. Mechanical input restrains PPARgamma2 expression and action to preserve mesenchymal stem cell multipotentiality. Bone. 2013; 52:454-64. [PubMed: 22951341]

24. Sen B, Styner M, Xie Z, Case N, Rubin CT, Rubin J. Mechanical loading regulates NFATc1 and beta-catenin signaling through a GSK3beta control node. Journal of Biological Chemistry. 2009; 284:34607-17. [PubMed: 19840939]

25. Styner M, Meyer MB, Galior K, Case N, Xie Z, Sen B, Thompson WR, Pike JW, Rubin J. Mechanical strain downregulates C/EBPbeta in MSC and decreases endoplasmic reticulum stress. PLoS One. 2012; 7:e51613. [PubMed: 23251594]

26. Thompson WR, Rubin CT, Rubin J. Mechanical regulation of signaling pathways in bone. Gene. 2012

27. Thompson WR, Guilluy C, Xie Z, Sen B, Brobst KE, Yen SS, Uzer G, Styner M, Case N, Burridge K, Rubin J. Mechanically Activated Fyn Utilizes mTORC2 to Regulate RhoA and Adipogenesis in Mesenchymal Stem Cells. Stem Cells. 2013

28. Sen B, Xie Z, Case N, Ma M, Rubin C, Rubin J. Mechanical strain inhibits adipogenesis in mesenchymal stem cells by stimulating a durable beta-catenin signal. Endocrinology. 2008; 149:6065-75. [PubMed: 18687779]

29. Sen B, Xie Z, Case N, Styner M, Rubin CT, Rubin J. Mechanical signal influence on mesenchymal stem cell fate is enhanced by incorporation of refractory periods into the loading regimen. Journal of Biomechanics. 2011; 44:593-9. [PubMed: 21130997]

30. Sen B, Xie Z, Case N, Thompson WR, Uzer G, Styner M, Rubin J. mTORC2 regulates mechanically induced cytoskeletal reorganization and lineage selection in marrow derived 
mesenchymal stem cells. Journal of bone and mineral research : the official journal of the American Society for Bone and Mineral Research. 2013

31. Chen J, Long F. beta-catenin promotes bone formation and suppresses bone resorption in postnatal growing mice. Journal of bone and mineral research : the official journal of the American Society for Bone and Mineral Research. 2013; 28:1160-9.

32. Scheller EL, Troiano N, Vanhoutan JN, Bouxsein MA, Fretz JA, Xi Y, Nelson T, Katz G, Berry R, Church CD, Doucette CR, Rodeheffer MS, Macdougald OA, Rosen CJ, Horowitz MC. Use of osmium tetroxide staining with microcomputerized tomography to visualize and quantify bone marrow adipose tissue in vivo. Methods Enzymol. 2014; 537:123-39. [PubMed: 24480344]

33. Pai VM, Kozlowski M, Donahue D, Miller E, Xiao X, Chen MY, Yu ZX, Connelly P, Jeffries K, Wen H. Coronary artery wall imaging in mice using osmium tetroxide and micro-computed tomography (micro-CT). Journal of Anatomy. 2012; 220:514-24. [PubMed: 22360411]

34. Kursawe R, Eszlinger M, Narayan D, Liu T, Bazuine M, Cali AM, D'Adamo E, Shaw M, Pierpont B, Shulman Gl, Cushman SW, Sherman A, Caprio S. Cellularity and adipogenic profile of the abdominal subcutaneous adipose tissue from obese adolescents: association with insulin resistance and hepatic steatosis. Diabetes. 2010; 59:2288-96. [PubMed: 20805387]

35. Fretz JA, Nelson T, Xi Y, Adams DJ, Rosen CJ, Horowitz MC. Altered metabolism and lipodystrophy in the early B-cell factor 1-deficient mouse. Endocrinology. 2010; 151:1611-21. [PubMed: 20172967]

36. Willis MS, Min JN, Wang S, McDonough H, Lockyer P, Wadosky KM, Patterson C. Carboxyl terminus of Hsp70-interacting protein (CHIP) is required to modulate cardiac hypertrophy and attenuate autophagy during exercise. Cell Biochemistry and Function. 2013

37. Luu YK, Lublinsky S, Ozcivici E, Capilla E, Pessin JE, Rubin CT, Judex S. In vivo quantification of subcutaneous and visceral adiposity by micro-computed tomography in a small animal model. Med Eng Phys. 2009; 31:34-41. [PubMed: 18486521]

38. Green DE, Adler BJ, Chan ME, Rubin CT. Devastation of adult stem cell pools by irradiation precedes collapse of trabecular bone quality and quantity. Journal of Bone and Mineral Research. 2012; 27:749-59. [PubMed: 22190044]

39. Fedorov A, Beichel R, Kalpathy-Cramer J, Finet J, Fillion-Robin JC, Pujol S, Bauer C, Jennings D, Fennessy F, Sonka M, Buatti J, Aylward S, Miller JV, Pieper S, Kikinis R. 3D Slicer as an image computing platform for the Quantitative Imaging Network. Magnetic Resonance Imaging. 2012; 30:1323-41. [PubMed: 22770690]

40. Yushkevich PA, Piven J, Hazlett HC, Smith RG, Ho S, Gee JC, Gerig G. User-guided 3D active contour segmentation of anatomical structures: significantly improved efficiency and reliability. Neuroimage. 2006; 31:1116-28. [PubMed: 16545965]

41. Schreiber JJ, Anderson PA, Rosas HG, Buchholz AL, Au AG. Hounsfield units for assessing bone mineral density and strength: a tool for osteoporosis management. Journal of Bone and Joint Surgery. 2011; 93:1057-63. [PubMed: 21655899]

42. Aamodt A, Kvistad KA, Andersen E, Lund-Larsen J, Eine J, Benum P, Husby OS. Determination of Hounsfield value for CT-based design of custom femoral stems. Journal of Bone and Joint Surgery. British Volume. 1999; 81:143-7.

43. Pagnotti GM, Adler BJ, Green DE, Chan ME, Frechette DM, Shroyer KR, Beamer WG, Rubin J, Rubin CT. Low magnitude mechanical signals mitigate osteopenia without compromising longevity in an aged murine model of spontaneous granulosa cell ovarian cancer. Bone. 2012; 51:570-7. [PubMed: 22584009]

44. Rossmeisl M, Rim JS, Koza RA, Kozak LP. Variation in type 2 diabetes-related traits in mouse strains susceptible to diet-induced obesity. Diabetes. 2003; 52:1958-66. [PubMed: 12882911]

45. Bartelt A, Beil FT, Schinke T, Roeser K, Ruether W, Heeren J, Niemeier A. Apolipoprotein Edependent inverse regulation of vertebral bone and adipose tissue mass in C57B1/6 mice: modulation by diet-induced obesity. Bone. 2010; 47:736-45. [PubMed: 20633710]

46. Machwate M, Zerath E, Holy X, Hott M, Modrowski D, Malouvier A, Marie PJ. Skeletal unloading in rat decreases proliferation of rat bone and marrow-derived osteoblastic cells. Am J Physiol. 1993; 264:E790-9. [PubMed: 8498500] 
47. Rittweger J, Winwood K, Seynnes O, de Boer M, Wilks D, Lea R, Rennie M, Narici M. Bone loss from the human distal tibia epiphysis during 24 days of unilateral lower limb suspension. $\mathrm{J}$ Physiol. 2006; 577:331-7. [PubMed: 17023509]

48. Schwartz AV, Sigurdsson S, Hue TF, Lang TF, Harris TB, Rosen CJ, Vittinghoff E, Siggeirsdottir K, Sigurdsson G, Oskarsdottir D, Shet K, Palermo L, Gudnason V, Li X. Vertebral bone marrow fat associated with lower trabecular BMD and prevalent vertebral fracture in older adults. The Journal of clinical endocrinology and metabolism. 2013

49. Patsch JM, Li X, Baum T, Yap SP, Karampinos DC, Schwartz AV, Link TM. Bone marrow fat composition as a novel imaging biomarker in postmenopausal women with prevalent fragility fractures. Journal of Bone and Mineral Research. 2013

50. Spatz JM, Ellman R, Cloutier AM, Louis L, van Vliet M, Suva LJ, Dwyer D, Stolina M, Ke HZ, Bouxsein ML. Sclerostin antibody inhibits skeletal deterioration due to reduced mechanical loading. Journal of Bone and Mineral Research. 2013; 28:865-74. [PubMed: 23109229]

51. Bielohuby M, Matsuura M, Herbach N, Kienzle E, Slawik M, Hoeflich A, Bidlingmaier M. Shortterm exposure to low-carbohydrate, high-fat diets induces low bone mineral density and reduces bone formation in rats. Journal of bone and mineral research : the official journal of the American Society for Bone and Mineral Research. 2010; 25:275-84.

52. Bredella MA, Torriani M, Ghomi RH, Thomas BJ, Brick DJ, Gerweck AV, Rosen CJ, Klibanski A, Miller KK. Vertebral bone marrow fat is positively associated with visceral fat and inversely associated with IGF-1 in obese women. Obesity (Silver Spring). 2011; 19:49-53. [PubMed: 20467419]

53. de Paula FJ, Dick-de-Paula I, Bornstein S, Rostama B, Le P, Lotinun S, Baron R, Rosen CJ. VDR haploinsufficiency impacts body composition and skeletal acquisition in a gender-specific manner. Calcified Tissue International. 2011; 89:179-91. [PubMed: 21637996]

54. Rantalainen T, Nikander R, Heinonen A, Cervinka T, Sievanen H, Daly RM. Differential effects of exercise on tibial shaft marrow density in young female athletes. Journal of Clinical Endocrinology and Metabolism. 2013; 98:2037-44. [PubMed: 23616150]

55. Turello RSD, Hartman HA. A modification of the osmium tetroxide post-fixation technique for the demonstration of extracellular lipid in paraffin-embedded tissue sections. Journal of Histotechnology. 1984:7.

56. Di lorgi N, Mo AO, Grimm K, Wren TA, Dorey F, Gilsanz V. Bone acquisition in healthy young females is reciprocally related to marrow adiposity. Journal of Clinical Endocrinology and Metabolism. 2010; 95:2977-82. [PubMed: 20392872]

57. Oguz I, Yaxley R, Budin F, Hoogstoel M, Lee J, Maltbie E, Liu W, Crews FT. Comparison of Magnetic Resonance Imaging in Live vs. Post Mortem Rat Brains. PLoS One. 2013; 8:e71027. [PubMed: 23967148]

58. Tremoleda JL, Khalil M, Gompels LL, Wylezinska-Arridge M, Vincent T, Gsell W. Imaging technologies for preclinical models of bone and joint disorders. EJNMMI research. 2011; 1:11. [PubMed: 22214535]

59. Chen J, Long F. beta-catenin promotes bone formation and suppresses bone resorption in postnatal growing mice. J Bone Miner Res. 2013; 28:1160-9. [PubMed: 23188722]

60. Schneider U, Pedroni E, Lomax A. The calibration of CT Hounsfield units for radiotherapy treatment planning. Physics in Medicine and Biology. 1996; 41:111-24. [PubMed: 8685250]

61. Wellard RM, Briellmann RS, Jennings C, Jackson GD. Physiologic variability of single-voxel proton MR spectroscopic measurements at 3T. AJNR. American Journal of Neuroradiology. 2005; 26:585-90. [PubMed: 15760870]

62. Bu S, Chen Y, Wang S, Zhang F, Ji G. Treadmill training regulates beta-catenin signaling through phosphorylation of GSK-3beta in lumbar vertebrae of ovariectomized rats. European Journal of Applied Physiology and Occupational Physiology. 2012

63. Cohen A, Dempster DW, Recker RR, Lappe JM, Zhou H, Zwahlen A, Muller R, Zhao B, Guo X, Lang T, Saeed I, Liu XS, Guo XE, Cremers S, Rosen CJ, Stein EM, Nickolas TL, McMahon DJ, Young P, Shane E. Abdominal fat is associated with lower bone formation and inferior bone quality in healthy premenopausal women: a transiliac bone biopsy study. Journal of Clinical Endocrinology and Metabolism. 2013 
64. Bredella MA, Lin E, Gerweck AV, Landa MG, Thomas BJ, Torriani M, Bouxsein ML, Miller KK. Determinants of bone microarchitecture and mechanical properties in obese men. Journal of Clinical Endocrinology and Metabolism. 2012; 97:4115-22. [PubMed: 22933540] 


\section{Highlights}

- High fat diet (HFD) increases marrow adipose tissue (MAT) similar to diet effect on visceral white fat depots.

- Running exercise significantly prevents MAT accumulation in regular diet and HFD-fed mice.

- Exercise limitation of MAT is associated with an increase in bone quantity.

- Reliable quantification and visualization of MAT in the mouse femur is demonstrated via osmium stain and volumetric micro-CT image analysis. 
A. raw unaligned $\mu \mathrm{CT}$

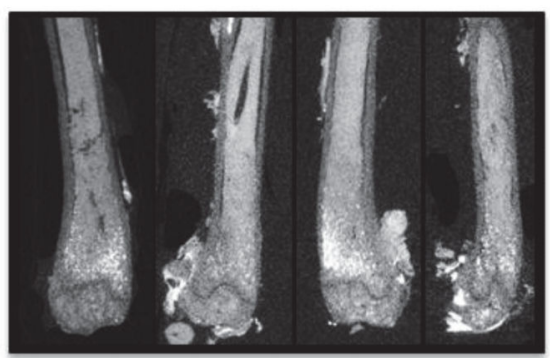

D. average $\mu \mathrm{CT}$

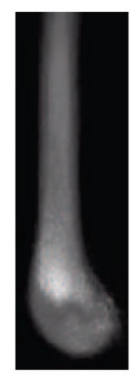

Figure 1. Methods overview

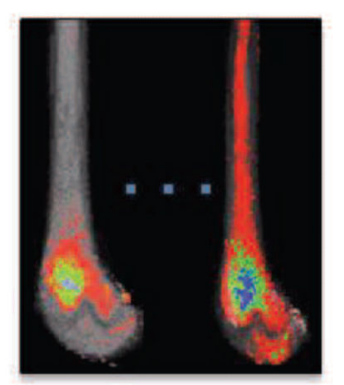

B. aligned $\mu$ CT

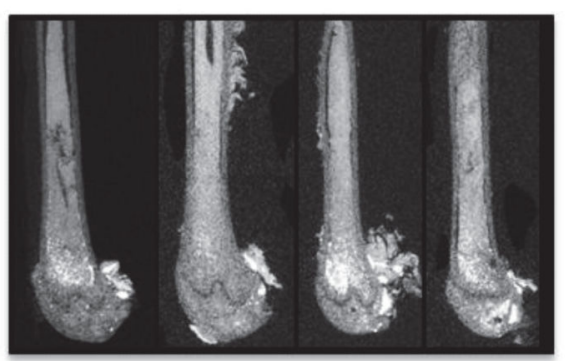

F. osmium

labels in 3D

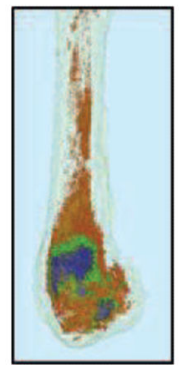

C. masked $\mu \mathrm{CT}$

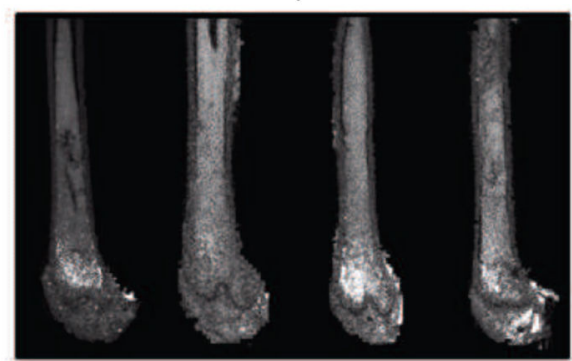

H. regional volumes
G. regions in 3D

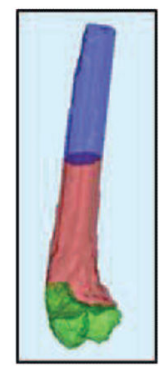

Figure 1. Overview of method for visualization and quantification of marrow adipose tissue (MAT)

Osmium-stained femorae were visualized via $\mu \mathrm{CT}$. Femorae (A) were rigidly aligned (B). Bone masks (C) were averaged (D). Osmium within the bone mask was quantified as volumetric (mm3) measurements of low (red), mid (green) and high (blue) osmium containing regions in the femur and $(\mathrm{E})$ overlaid on $\mu \mathrm{CT}$ images for viewing. 3D rendering of osmium regions $(\mathrm{F})$ with same coloring as $3 \mathrm{E}$, colors slightly offset due to transparent bone mask. In $(\mathrm{G})$ we subdivided the femur into three anatomical regions of interest. $(\mathrm{H})$ This is a pictorial representation of a data spreadsheet containing regional osmium measurements as osmium volume normalized to total femoral volume (in \%). 


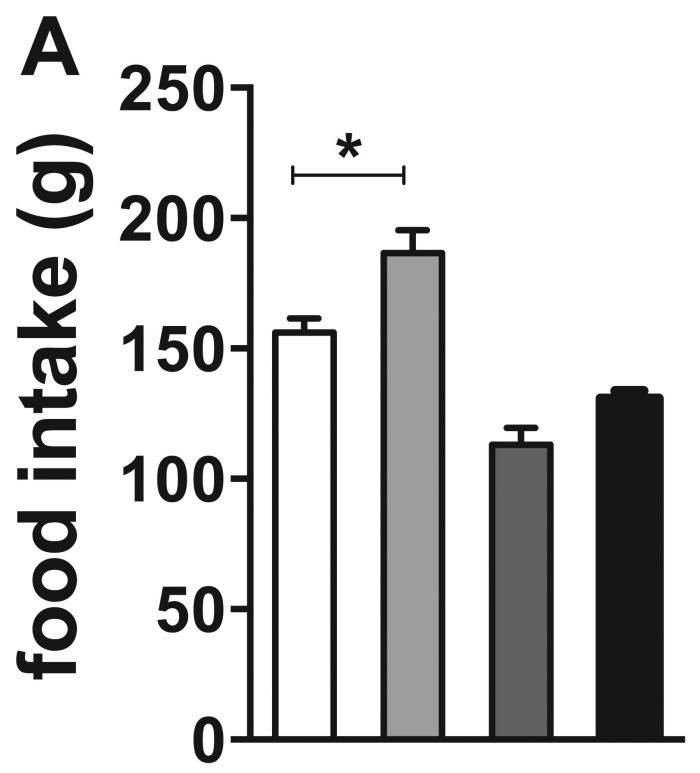

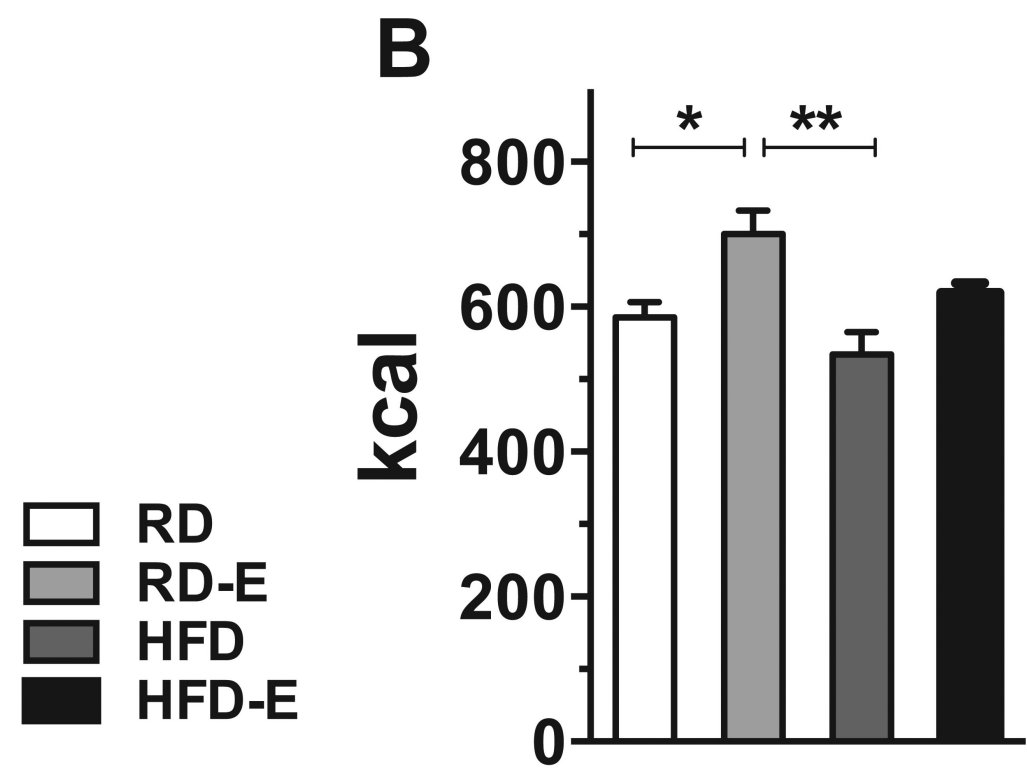
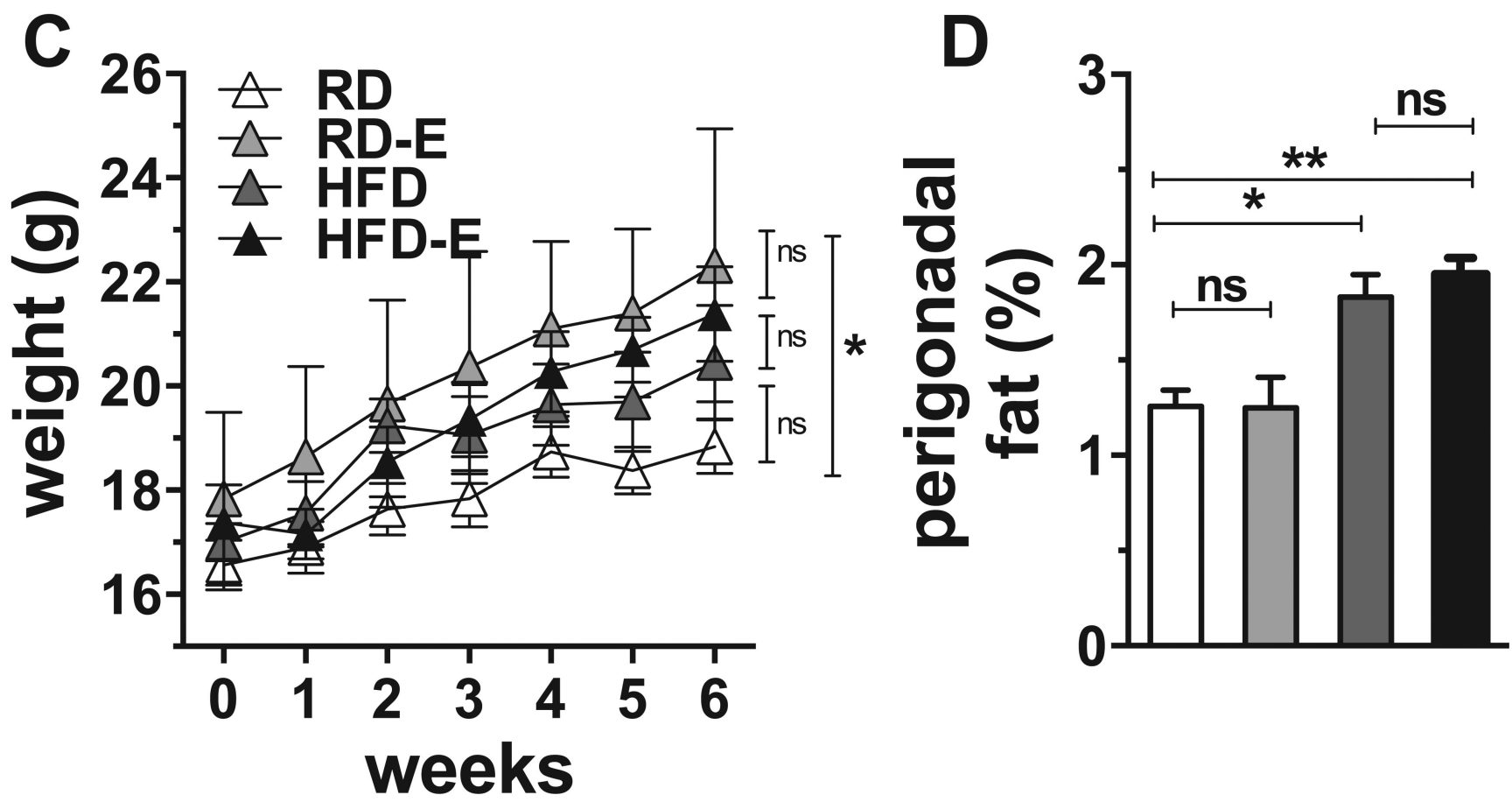

Figure 2. White adipose tissue and weight are increased by HFD diet C57BL/6 Mice had access to running wheels starting at the same time as the change in diet, age 8 wk. (A) Food intake. (B) Kcal consumed. (C) Body weight (D) Perigonadal fat pad weight normalized to body weight. Results expressed as means \pm SEM. 
A
Sagittal

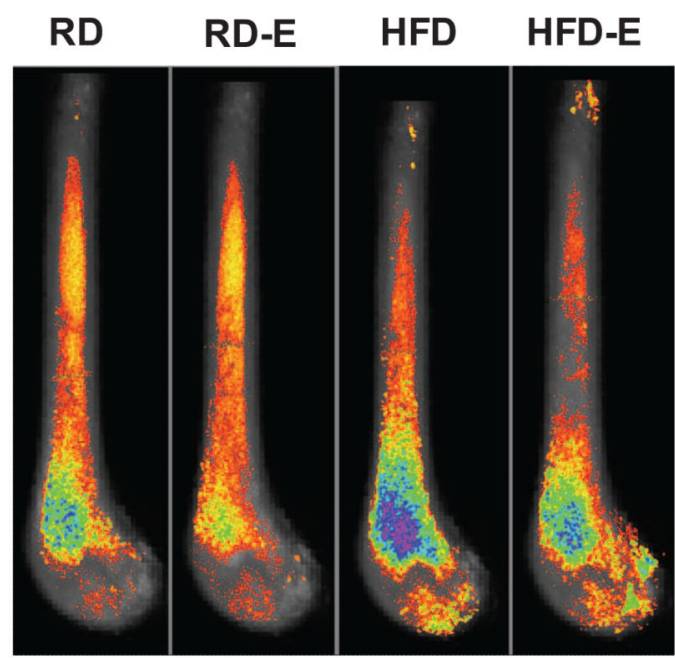

D
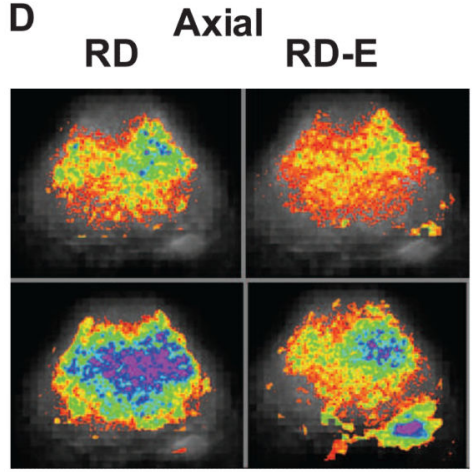

HFD

\section{$E$}

B

Coronal

C

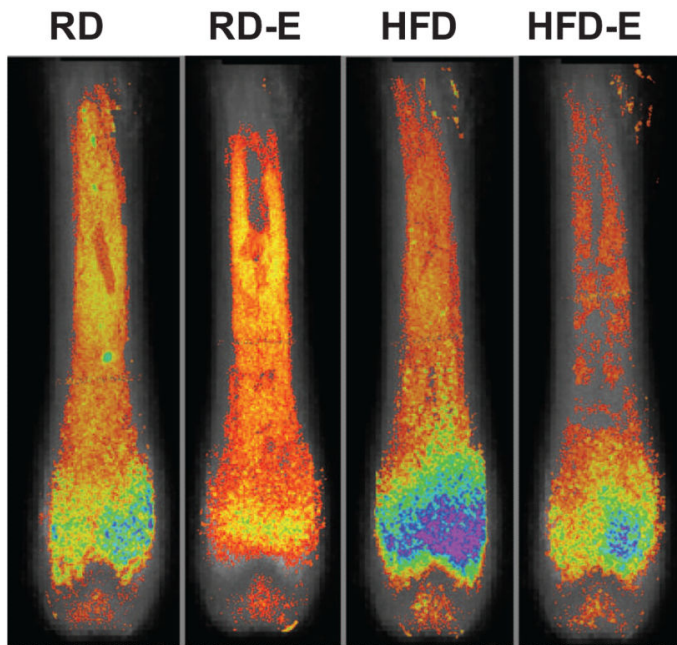

$\mathbf{F}$
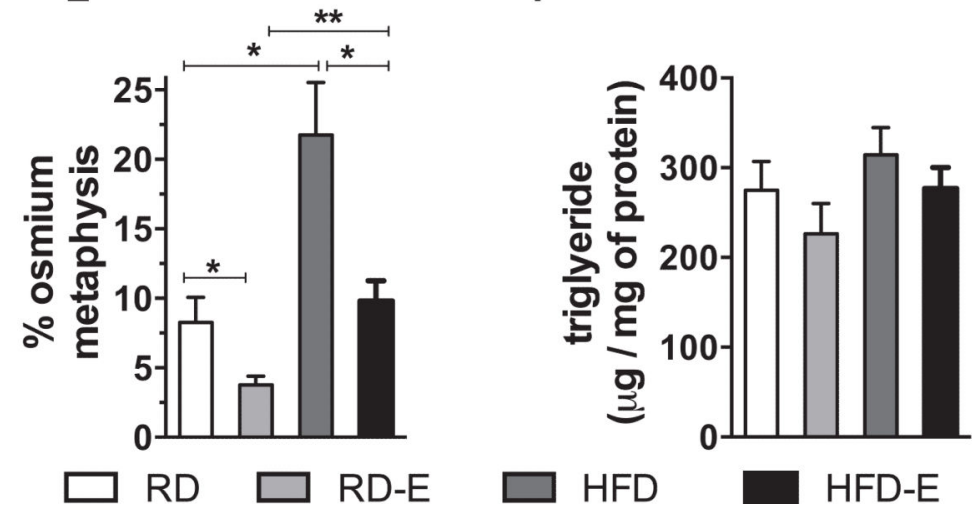

Figure 3. Exercise suppresses marrow adiposity despite HFD diet

8 wk old C57BL/6 mice were fed a RD or HFD diet for 6 weeks and given access to voluntary running wheels. Visualization of osmium stain by $\mu \mathrm{CT}$ is demonstrated in the sagittal (A) coronal (B), and axial (D) planes. (C) Osmium heat map and pictorial representation of the anatomic planes demonstrated in A, B, D. Each image represents overlaid average of $n=5$ mice. (E) Quantification of osmium in metaphysis as a measure of MAT. (F) Triglyceride content of the femur ( $\mathrm{n}=5$ per group). Results expressed as means \pm SEM. 

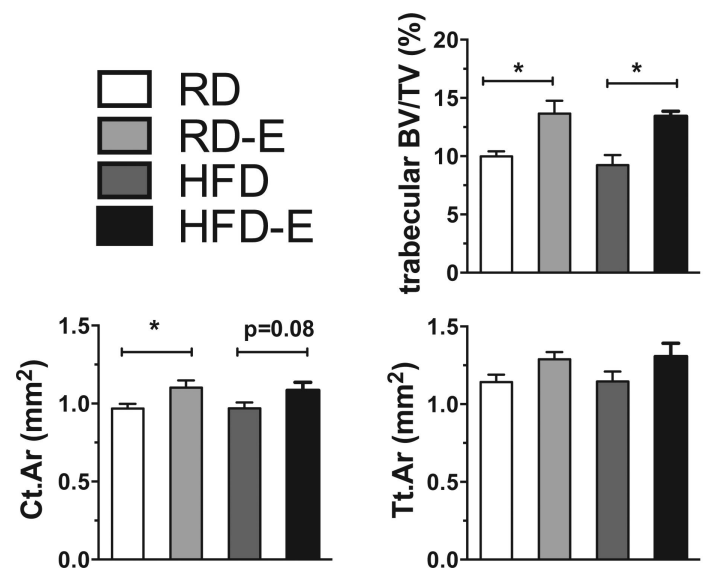
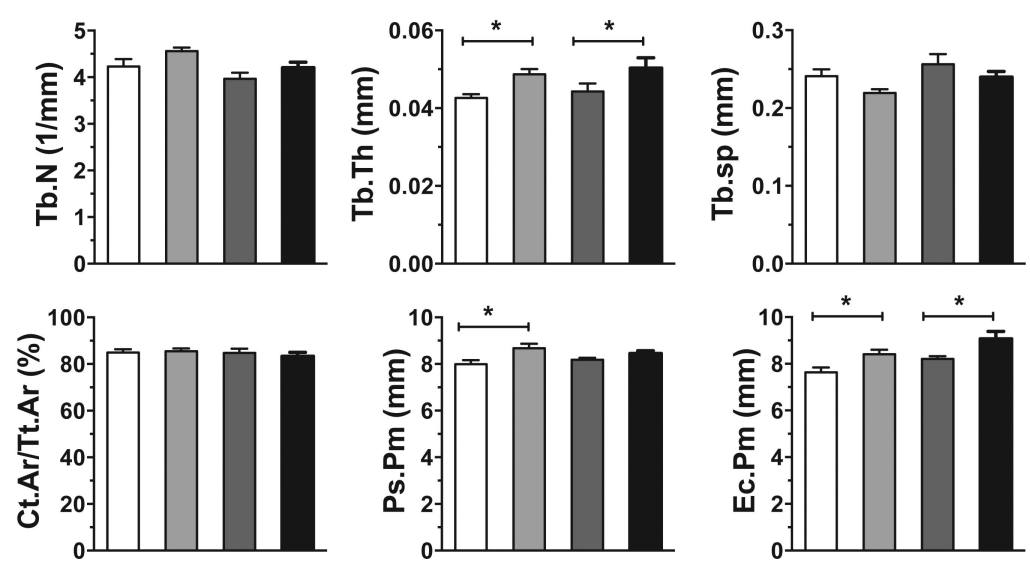

Figure 4. Running increases bone quantity

Bone quantity was measured in the proximal tibial metaphysis and diaphysis to assess effects of 6 weeks of HFD and exercise via $\mu$ CT. 


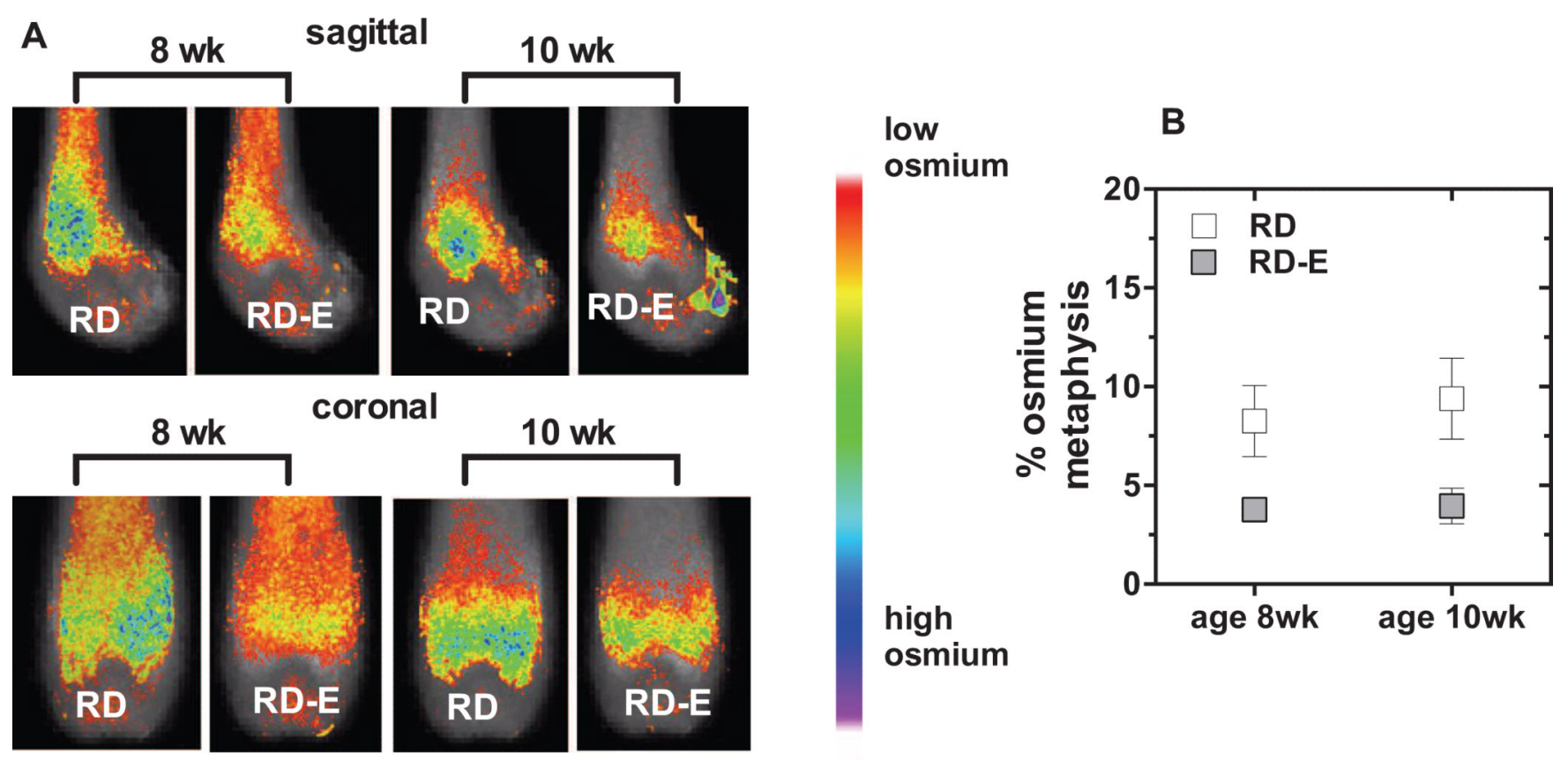

Figure 5. Exercise reduces MAT in skeletally mature mice

Eight week-old and 10 week-old C57 BL/6 mice were fed a RD and provided access to running wheels (A) Visualization of osmium stain by $\mu \mathrm{CT}$ is demonstrated in the sagittal and coronal planes. (C) Quantification of osmium in the metaphysis as a measure of MAT. Results expressed as means \pm SEM. 
Table 1

Running parameters (expressed as mean $\pm \mathrm{SD}$ ).

\begin{tabular}{l|c|c|c|c}
\hline \multirow{2}{*}{} & \multicolumn{2}{|c|}{8 week } & 10 week & \multirow{2}{*}{ P value } \\
\cline { 2 - 4 } & RD & HFD & RD & \\
\hline Average distance $(\mathrm{km} /$ day $)$ & $10.9 \pm 3.2$ & $11.0 \pm 1.6$ & $12.0 \pm 2.3$ & $\mathrm{P}=0.75$ \\
\hline Average time $(\mathrm{min} /$ day $)$ & $358 \pm 65$ & $367 \pm 55$ & $349 \pm 64$ & $\mathrm{P}=0.90$ \\
\hline Average speed $(\mathrm{km} / \mathrm{hr})$ & $2.02 \pm 0.38$ & $2.14 \pm 0.09$ & $2.0 \pm 0.21$ & $\mathrm{P}=0.731$ \\
\hline
\end{tabular}




\section{Table 2}

Marrow adipose tissue ( $\%$ osmium in $\mathrm{mm}^{3} /$ total bone volume as mean $\pm \mathrm{SD}$ ).

\begin{tabular}{|l|c|c|c|c|c|c|}
\hline \multirow{2}{*}{} & \multicolumn{4}{|c|}{8 week } & \multicolumn{2}{c|}{ 10 week } \\
\cline { 2 - 7 } & RD & RDE & HFD & HFD-E & RD & RDE \\
\hline Epiphysis & $1.6 \pm 0.53$ & $1.1 \pm 0.32$ & $7.4 \pm 5.5$ & $5.3 \pm 2.2$ & $0.85 \pm 0.34$ & $1.5 \pm 1.9$ \\
\hline Metaphysis & $8.5 \pm 3.4$ & $3.6 \pm 1.3^{a}$ & $22 \pm 8.2^{a}$ & $9.6 \pm 2.7^{b}$ & $9.4 \pm 4.3$ & $4.4 \pm 2.4^{c}$ \\
\hline Diaphysis & $1.4 \pm 1.4$ & $1.3 \pm 1.1^{2}$ & $0.94 \pm 0.30$ & $0.62 \pm 0.26$ & $0.14 \pm 0.089$ & $0.04 \pm 0.055$ \\
\hline Metaphysis+diaphysis & $6.0 \pm 2.0$ & $2.9 \pm 1.3^{a}$ & $15 \pm 5.2^{a}$ & $6.6 \pm 2.1^{b}$ & $6.1 \pm 2.8$ & $2.8 \pm 1.6^{c}$ \\
\hline Total femur & $5.0 \pm 1.6$ & $2.4 \pm 1.1^{a}$ & $13 \pm 5.1^{a}$ & $6.2 \pm 1.8^{b}$ & $5.0 \pm 2.0$ & $2.6 \pm 0.89^{c}$ \\
\hline
\end{tabular}

$a_{\mathrm{p}<0.05 \text { compared with RD }}$

$b_{\mathrm{p}<0.05 \text { compared with HFD }}$

${ }_{\mathrm{p}}^{c}<0.05$ compared with Adult RD 
Table 3

Bone microarchitecture measurements by $\mu \mathrm{CT}$ (mean $\pm \mathrm{SD}$ ).

\begin{tabular}{|l|c|c|c|c|}
\hline & RD & RD-E & HFD & HFD-E \\
\hline Trabecular BV/TV (\%) & $10 \pm 0.97$ & $14 \pm 1.9^{a}$ & $9.2 \pm 1.5$ & $13 \pm 0.74^{b}$ \\
\hline Tb.N (1/mm) & $4.2 \pm 0.35$ & $4.6 \pm 0.13$ & $4.0 \pm 0.22$ & $4.2 \pm 0.20$ \\
\hline Tb.Th (mm) & $0.04 \pm 0.002$ & $0.05 \pm 0.002^{a}$ & $0.04 \pm 0.004$ & $0.05 \pm 0.005$ \\
\hline Tb.Sp (mm) & $0.24 \pm 0.02$ & $0.22 \pm 0.009$ & $0.26 \pm 0.022$ & $0.24 \pm 0.013$ \\
\hline Ct.Ar (mm2) & $0.97 \pm 0.066$ & $1.1 \pm 0.080^{a}$ & $0.97 \pm 0.066$ & $1.1 \pm 0.089$ \\
\hline Tt.Ar (mm2) & $1.1 \pm 0.11$ & $1.3 \pm 0.08$ & $1.1 \pm 0.11$ & $1.3 \pm 0.15$ \\
\hline Ct.Ar/Tt.Ar (\%) & $85 \pm 3.1$ & $86 \pm 2.0$ & $85 \pm 3.2$ & $83 \pm 3.0$ \\
\hline Ct.Th (mm) & $0.10 \pm 0.008$ & $0.10 \pm 0.007$ & $0.10 \pm 0.006$ & $0.11 \pm 0.008$ \\
\hline Ps.Pm (mm) & $8.0 \pm 0.04$ & $8.7 \pm 0.33^{a}$ & $8.2 \pm 0.15$ & $8.5 \pm 0.20$ \\
\hline Ec.Pm (mm) & $7.6 \pm 0.46$ & $8.4 \pm 0.32^{a}$ & $8.2 \pm 0.21$ & $9.1 \pm 0.54^{b}$ \\
\hline
\end{tabular}

$a_{\mathrm{p}<0.05 \text { compared with RD }}$

${ }_{\mathrm{p}}^{b}<0.05$ compared with HFD 